\title{
Why has demand for platelet components increased? A review
}

Lise J. Estcourt ${ }^{1,2}$

1. NHS Blood and Transplant, Oxford, United Kingdom.

2. Radcliffe Department of Medicine, University of Oxford, Oxford, United Kingdom.

Running title: Why has demand for platelet components increased?

Word count: Main text 3469; Tables 2; Figures 4

Correspondence: Dr Lise J Estcourt, NHS Blood and Transplant, Level 2, John Radcliffe Hospital, Oxford, OX3 9BQ, United Kingdom; tel +44 (0) 1865 387974; email- lise.estcourt@nhsbt.nhs.uk. 


\section{Abstract}

Platelet transfusions are used in clinical practice to prevent and treat haemorrhage in thrombocytopenic patients or patients with severe platelet dysfunction. In the UK, and abroad there has been a recent rise in platelet component demand. The three largest patient groups that use platelet components are patients with haematological malignancies (up to $67 \%$ ), patients receiving cardiac surgery (up to $10 \%$ ) and patients receiving intensive care (up to $8 \%$ ). This review has explored some of the factors that may explain this recent trend within these three main groups. These factors include a rise in the general population, an ageing population, an increase in the incidence and prevalence of haematological malignancies, and changes in the management of patients with haematological malignancies. However, the only data available that can be correlated directly with national component data are the size of the total population. There is no evidence to support the premise that use of platelet components in patients receiving cardiac surgery or intensive care treatment is rising over and above the general rise in the population, but the data are sparse.

\section{Introduction}

Platelet transfusions are used in clinical practice to prevent and treat haemorrhage in thrombocytopenic patients or patients with severe platelet dysfunction (BCSH 2003, Miller, et al 2007).

In the UK, over the last decade, there has been a considerable increase in the demand for platelet components of approximately 24\% between 2002 and 2012 (Bolton-Maggs, et al 2013, Taylor, et al 2009). This is not an isolated phenomenon, in the United States the number of platelet components transfused has increased by 32\% between 2004 and 2011 (Report of the US Department of Health and Human Services 2011, Whitaker, et al 2008, Whitaker and Hinkins 2013, Whitaker and Sullivan 2007). A similar pattern has been seen in Europe (Table 1) and Australia (Commonwealth of Australia 2008, Commonwealth of Australia 2013). 
Currently, the use of platelet transfusions in patients with haematological disorders accounts for a large proportion (up to 67\%) of all platelet components (PCs) issued (Cameron, et al 2007, Charlton, et al 2014, Greeno, et al 2007, Jones, et al 2013, Pendry and Davies 2011). The next two biggest groups of patients who receive platelet components are cardiac surgery patients ( 7 to $10 \%$ of usage) (Cameron, et al 2007, Charlton, et al 2014, Jones, et al 2013, Pendry and Davies 2011) and intensive care unit (ICU) patients (5 to $9 \%$ of usage) (Cameron, et al 2007, Charlton, et al 2014, Pendry and Davies 2011). In patients with haematological disorders the majority of platelet transfusions are given to prevent bleeding, 84\% were given prophylactically in a recent national audit (Estcourt, et al 2012).

This review will explore possible factors to explain this changing demand. These include:

- Increasing size of the general population

- Increasing age of the general population

- Changes to the proportion of platelet components that are given inappropriately

- Changes to platelet component specifications

- Changes to the incidence or prevalence of haematological disorders

- The introduction of more intensive treatment regimens for patients with haematological malignancies

- Changes to the management of patients receiving cardiac surgery

- Changes to the number of patients receiving intensive care

\section{Increase in the size of the general population}

Although the population of the UK has increased, this does not account for the majority of the rise in demand (Fig. 1A). Once the increasing population has been taken in to account demand has still increased by $15.6 \%$ in the UK over the last decade, with 4.2 components per 1000 population being issued in 2002, compared to 4.9 components per 1000 population in 2012. Multiple European countries 
have also shown an increasing trend in platelet usage when adjusted for their total population (Table 1). The only deviation from this trend was for the Netherlands which had the highest rate of platelet usage in the 2001-2002 time period. This increasing trend has also been seen in Australia where demand has increased by approximately 18\% from 2003-2004 to 2012-2013 (Commonwealth of Australia 2008, Commonwealth of Australia 2013). An increase in the size of the general population therefore only explains part of the trend.

\section{Increase in the age of the general population}

The increasing trend in the demand for PCs cannot be adjusted for the age of the population because the ages of PC recipients are unknown for the national data sets. The median age of patients receiving platelet transfusions in the UK is approximately 60 years of age (Charlton, et al 2014, Estcourt, et al 2012; Wells, et al 2009). No other published multicentre audit has reported the age of PC recipients. The population of the UK is ageing. Over the last decade (2002 to 2012) the total UK population has increased by $7.3 \%$ (59.4 million to 63.7 million), however, the population aged 60 years of age or older has increased by $17.4 \%$ (12.3 million to 14.5 million) (Office of National Statistics (ONS) 2013b). An increase in the age of the population will therefore account for part of the trend in the UK, whether this is true for the rest of the world is unknown.

\section{Inappropriate use of platelet components}

Levels of inappropriate use may vary between countries and over time. An increase in inappropriate use could have been a potential explanation for the rise in demand if it had only been seen in one country and that country had recently changed the way it trained its physicians. However, it is unlikely that there has been a sudden rise in inappropriate prescribing of blood components around the world.

The two large national UK platelet transfusion audits both showed a significant amount of inappropriate usage (Estcourt, et al 2012, Qureshi, et al 2007). However, the audit in 2010 did not demonstrate that prescribing practice was significantly worse than the preceding audit in 2007 . Although the two audits 
did differ in their audit criteria and participants (the first audit included all patient groups whereas the second audit only included haematology patients), $43 \%$ of platelet transfusions were outside the audit standard in 2007 (Qureshi, et al 2007), whereas only 28\% of all platelet transfusions were outside the audit standard in 2010 (Estcourt, et al 2012). There is therefore no evidence that there has been a rise in inappropriate prescribing of blood components in the UK, however due to differences between the two audits we cannot say whether inappropriate usage has decreased.

\section{Changes to product specification}

There is insufficient evidence available to comment on whether changes to platelet component specifications have had an effect on platelet component demand. Platelet component specifications vary significantly from country to country. Variations include: the proportion of patients receiving apheresis platelets .(van der Poel, et al 2011a, van der Poel, et al 2011b, van der Poel, et al 2011c, van der Poel, et al 2011d); the proportion who suspend platelets in platelet additive solutions or plasma (Pietersz, et al 2012); and the platelet dose within each platelet component (Pietersz, et al 2012). When we consider changes to components that may affect the number of platelet components used. The age of platelet components does not appear to affect the transfusion interval (MacLennan, et al 2013). It is unknown whether apheresis components affect the platelet transfusion interval (Heddle, et al 2008). Pathogen reduced platelet components may increase the number of platelet transfusions given per patient (Butler, et al 2013).Doubling the platelet component dose increases the platelet transfusion interval (Slichter, et al 2010). However increasing the dose from $2.2 \times 10^{11} / \mathrm{m}^{2}$ to $4.4 \times 10^{11} / \mathrm{m}^{2}$ did not increase the number of platelet transfusions given (Slichter, et al 2010). The effect of smaller variations in platelet component dose are unknown.

\section{Increased incidence and prevalence of haematological malignancies}

Haematological malignancies constituted $8 \%$ of all new cancers in the UK (2007-09) (ONS 2012) and 9\% of all new cancers in the US (CDC 2008; CDC 2012) and their incidence is increasing in both the UK (Fig. 
2) and other countries throughout the world (Chihara, et al 2014, National Cancer Institute 2013a, National Cancer Institute 2013b, National Cancer Institute 2013c, National Cancer Institute 2013d). Not only are the numbers of new cases increasing, but, also, the survival of patients who have previously been diagnosed with a haematological malignancy is also increasing (Fig. 3). This means that the overall prevalence of patients with haematological disorders who may require platelet transfusions is rising and this trend is continuing to rise. Patients who survive their initial treatment may require further treatment due to relapse of their haematological malignancy, for example, over $50 \%$ of patients who receive an autologous HSCT for multiple myeloma relapse and require further treatment (Fernandez de Larrera, et al 2014). The increased burden of haematological malignancies within the population could explain part of the increase in demand.

There is insufficient epidemiological data to confidently state that the incidence of myelodysplastic syndromes (MDS) is rising (Ma 2012). A German study has shown no obvious trend in the agestandardised incidence of MDS from 1996 to 2006, and the age-standardised point prevalence remained stable throughout the study at 7 per 100,000 (Neukirchen, et al 2011). However, the incidence of MDS rises markedly with age. According to a US study the age-specific incidence at 60 to 65 is 5.4 per 100,000 per year, at 70 to 74 it is 16.6 per 100,000 per year, and by the age of 80 it is 36.2 per 100,000 per year (Ma, et al 2007). It is therefore likely that the incidence is rising in countries with an ageing population (Ma, et al 2007, Neukirchen, et al 2011). The UK is an example of a country with an ageing population, in 2002 the population 70 years of age, or older was 6.8 million, by 2012 it was 7.5 million, however by 2046 this figure is expected to double to 15 million (Office of National Statistics (ONS) 2013c).

In the UK national audit in 2010 the groups that used the largest number of platelet components were patients with acute myeloid leukaemia (29\%), lymphoma (19\%) and MDS (13\%) (Estcourt, et al 2012). Over the three month audit period, patients with acute myeloid leukaemia received a mean of 10.1 
platelet transfusions per patient, patients with myelodysplasia received a mean of 9.5 platelet transfusions per patient, whereas lymphoma patients received a mean of 6.7 platelet transfusions per patient (previously unpublished data). Therefore any increase in the prevalence of these disorders are likely to have the greatest impact on platelet component demand.

\section{Management of haematological disorders}

The improved survival rates referred to previously are due to the introduction of intensive chemotherapy treatments and the use of haemopoietic stem cell transplantation (HSCT) (Burnett, et al 2011, Fielding, et al 2007, Milligan, et al 2006, Patel, et al 2009).

Haematological malignancies and their treatment lead to prolonged periods of severe thrombocytopenia ( $\left.\leq 50 \times 10^{9} / \mathrm{I}\right)$, (De la Serna, et al 2008, Heddle, et al 2009, Rysler, et al 2010, Stanworth, et al 2013a, Wandt, et al 2012), during this thrombocytopenic period patients are at risk of severe and life-threatening haemorrhage (Slichter, et al 2010, Stanworth, et al 2013a). The majority of platelet transfusions given during this period are to prevent rather than treat bleeding when the platelet count falls below a threshold of $10 \times 10^{9} / \mathrm{L}$, unless there are other risk factors for bleeding (BCSH 2003, Estcourt, et al 2012). Therefore any increase in the number of patients receiving intensive chemotherapy or an HSCT will increase demand on the number of platelet components required.

In Europe, there has been a dramatic increase in the number of HSCT (Figure 4) (Passweg, et al 2012) (Passweg, et al 2013). Since 1990, the number of HSCT has risen from 4,200 to over 30,000 annually (Passweg, et al 2012). The most obvious recent trend has been the increase in allogeneic HSCT with a 37\% rise from 2005 to 2010 (Passweg, et al 2012). In 2011, 14,549 allogeneic stem cell transplants were performed in Europe, 48\% were for patients with acute leukaemia and 13\% were for patients with MDS (Passweg, et al 2013). This reflects an additional 9\% rise in the number of allogeneic HSCT compared to 2010. One of the trends noted within the most recent European Group for Bone Marrow 
Transplantation (EBMT) survey has been the increasing use of allogeneic HSCT to treat MDS (Passweg, et al 2013). This dramatic rise in the use of HSCT combined with an increasing incidence and prevalence of haematological malignancies, including MDS, is likely to be one of the major reasons behind the recent increase in demand for platelet components. The development of reduced intensity conditioning (RIC) regimens for allogeneic HSCT has been one of the major drivers for this rise in allogeneic HSCT. Although RIC HSCT requires less transfusion support than myeloablative HSCT it still require similar levels of transfusion support to patients receiving consolidation chemotherapy for acute leukaemia (unpublished data from TOPPS study) (Stanworth, et al 2013). In fact, a recent study showed that $14 \%$ of all platelet components issued were given to patients receiving a stem cell transplant (Charlton, et al 2014).

\section{Changes to the management of patients receiving cardiac surgery}

There is significant variability between and within countries in blood component use in patients receiving cardiac surgery (Allard, et al 2013; Snyder-Ramos, et al 2008). However, the introduction of near patient testing (rotational thromboelastometry) may lead to reductions in platelet component use (Anderson, et al 2006). Also, due to recent concern that, in cardiac surgery, platelet transfusions are associated with serious adverse events, it is unlikely that their use has risen dramatically (Bilgin, et al 2011, Spiess, et al 2004). Using the estimates from the EASTR study (data from 2001 to 2002) (Wells, et al 2009), approximately $10.5 \%$ of all platelet components were given to cardiac patients (6702 recipients receiving a mean of 2.1 platelet components). More recent estimates for the proportion of platelet components given to cardiac surgery patients are relatively similar ( 7 to $10 \%$ of usage). These estimates mean that when the overall increase in platelet use is taken in to account the total number of platelet components given to cardiac patients could have decreased by up to $13 \%$, or increased by $20 \%$ over the last decade (Cameron, et al 2007, Charlton, et al 2014, Jones, et al 2013, Pendry and Davies 2011). Therefore although the management of cardiac surgery patients has changed recently, with an increase in the number of cardiac stenting procedures and the trend to use dual anti-platelet therapy for 12 
months after acute coronary syndrome. These changes in management do not appear to have had a major impact on the total number of platelet components given to cardiac surgery patients.

\section{Changes to the number of patients receiving intensive care}

The ISOC study, (Stanworth, et al 2013b) a multicentre observational UK study showed that $9 \%$ of ICU patients required a platelet transfusion. A Canadian study, conducted between 1999 and 2007, showed a fall in the number of ICU episodes but a slight rise in the number of ICU bed-days (Garland, et al 2013). ICU bed-days comprised $2.3 \%$ of all hospital bed-days over the entire study with no increasing trend (Garland, et al 2013). Also, the Scottish Intensive Care Society Audit Group (SICSAG) has reported ICU admissions over the period of 2003 to 2012 (Scottish Intensive Care Society Audit Group 2013). There has been no significant increase in admissions ( $2.5 \%$ adjusted to the rise in the Scottish population, (Office of National Statistics (ONS) 2013a) 6.6\% unadjusted) to stand-alone ICUs that reported their figures for the entire period and did not change their status between stand-alone and combined ICU and high dependency units during this period. There has also been no change in the mean duration of admissions (Scottish Intensive Care Society Audit Group 2013). Obviously we cannot assess changes in severity of illness and dependency using this data, but it is unlikely that such differences would have a significant impact on overall platelet component demand. A large proportion of all ICU admissions are in men aged 60 to 79 years of age (The Health and Social Care Information Centre 2013), therefore although no trend in increasing use is present at the moment this may become relevant in the future as the population continues to age (Office of National Statistics (ONS) 2013b).

\section{So why hasn't demand for red blood cell components (RBC) also risen?}

$\mathrm{RBC}$ component demand has fallen (Fig 1B), yet we are seeing a dramatic increase in the demand for platelet components. Patients with haematological disorders require both red cell transfusion and 
platelet components when they are receiving intensive chemotherapy for an HSCT. There are two main reasons why an increase in the number of patients with haematological disorders and an increase in the intensity of their treatment are having a much smaller effect on the demand for RBC components.

Firstly, only $18 \%$ of red cell components are given to patients with haematological disorders, therefore any change in use in this patient group is going to have a much smaller effect on overall usage than it does on platelet components (Tinegate, et al 2013). Any increase will be overwhelmed by the dramatic decrease in red cell usage in surgical patients (Tinegate, et al 2013).

Secondly, the number of platelet components given to each patient per course of intensive chemotherapy or HSCT is much higher than the number of red cell transfusions they receive. For example, in the largest randomised controlled trial (RCT) of prophylactic platelet transfusions, (Slichter, et al 2010) patients received on average less than one red cell transfusion per course of treatment, whereas, they received a median of between 3 and 5 platelet transfusions per course of treatment. Also, fewer patients receive an RBC transfusion during their treatment. In an RCT that compared a prophylactic versus therapeutic platelet transfusion strategy, (Stanworth, et al 2013a) in the prophylactic arm, $89 \%$ of patients received at least one platelet transfusion, whereas only $67 \%$ received at least one red cell transfusion.

\section{Why have we only seen a rise in the use of platelet component use since 2008 in the UK?}

This may be because of two superimposed factors. Firstly, the proportion of platelet components used in many other patient groups has decreased. Using the estimates from the EASTR study (data from 2001 to 2002) (Wells, et al 2009), approximately $37.7 \%$ of all platelet components were given to haematology patients (10539 recipients receiving a mean of 4.8 platelet components). More recent estimates for the number of platelet components given to haematology patients are much higher (up to 67\%) of all platelet components (PCs) issued (Cameron, et al 2007, Charlton, et al 2014, Greeno, et al 2007, Jones, 
et al 2013, Pendry and Davies 2011). This could mean that as platelet usage decreased in other patient groups the influence of any specific factors affecting haematology patients could have had a much greater effect on platelet component usage. Due to differences in the way data has been categorised the groups that have seen the most significant fall in platelet component demand cannot be accurately identified.

\section{Summary}

The most likely reasons for the increase in platelet component demand in combination are:

1) An increase in the general population in the UK. The UK population has risen by $7.3 \%$ over the last decade.

2) An ageing population. The UK population aged over 60 years of age has increased by $17.4 \%$ (12.3 million to 14.5 million) from 2002 to 2012.

3) An increase in the incidence and prevalence of haematological malignancies. The incidence of non-Hodgkin lymphoma has increased by approximately $12 \%$ in the last decade and the incidence of myeloma has increased by between 7 and $14 \%$. Overall survival for all haematological malignancies has improved.

4) A significant change in the management of patients with haematological malignancies, with a dramatic rise in the use of allogeneic HSCT.

The only data available that can be correlated directly with national component data are the size of the total population. All the other factors mentioned are plausible but we have no conclusive evidence to prove the validity of these hypotheses. There are many pieces of information that are not available that would provide a more accurate picture of why platelet demand has changed (Table 2). Hopefully, this data will be available in the future with increased use of electronic records. 
We are unlikely to be able to change any of the factors mentioned above, and therefore have to consider ways of preserving the national blood supply so that any further expected increase in demand can be accommodated. This includes methods to reduce inappropriate use, and also considering whether we are currently using prophylactic platelet transfusions in the most effective way.

At the moment we use a standard platelet count threshold of $10 \times 10^{9} / \mathrm{L}$, however some patients are at a higher risk of bleeding than others. We therefore need further research to help us to stratify patients in to those who are at a low or high risk of severe bleeding. A UK-wide case-control study is currently open to study risk factors for intracranial haemorrhage in patients with haematological malignancies (Estcourt, et al 2014). Understanding patient risk factors in other settings e.g. cardiac surgery and intensive care is also very important but has been studied far less.

We also need to consider whether some patients may receive less benefit from a prophylactic platelet transfusion than others (Stanworth, et al 2014). Alternative haemostatic agents e.g. antifibrinolytics could also be considered. There is insufficient evidence for their use at the moment in patients with haematological malignancies (Wardrop, et al 2013). However, in a large systematic review antifibrinolytics have been shown to be effective at reducing blood loss and bleeding in surgical patients (Henry, et al 2011). The review did not include platelet component use as one of its outcomes. However, it is likely that if blood loss and RBC component use were reduced by antifibrinolytics then platelet component use is also likely to have reduced. Therefore the use of antifibrinolytics in cardiac surgery patients may reduce platelet component use.

\section{Acknowledgements}

I would like to thank Dr Simon Stanworth and Professor Mike Murphy who have kindly reviewed and commented on this manuscript. 
I have no competing interests to declare 


\section{References}

Allard, S., Grant-Casey, J., Murphy, G., Herbertson, M., Gill, R. \& Murphy, M. (2013) National comparative audit of blood and component use in cardiac surgery. Transfusion Medicine, 23 Supp 2, 39 (Abstract PO23).

Anderson, L., Quasim, I., Soutar, R., Steven, M., Macfie, A. \& Korte, W. (2006) An audit of red cell and blood product use after the institution of thromboelastometry in a cardiac intensive care unit. Transfusion Medicine, 16, 31-39.

Baldomero, H., Gratwohl, M., Gratwohl, A., Tichelli, A., Niederwieser, D., Madrigal, A., Frauendorfer, K., European Group for, B. \& Marrow Transplantation, E. (2011) The EBMT activity survey 2009: trends over the past 5 years. Bone Marrow Transplantation, 46, 485-501.

BCSH (2003) British Committee for Standards in Haematology: Guidelines for the use of platelet transfusions. British Journal of Haematology, 122, 10-23.

Bilgin, Y.M., van de Watering, L.M., Versteegh, M.I., van Oers, M.H., Vamvakas, E.C. \& Brand, A. (2011) Postoperative complications associated with transfusion of platelets and plasma in cardiac surgery. Transfusion, 51, 2603-2610.

Bolton-Maggs, P., Cohen, H. \& on behalf of the Serious Hazards of Transfusion (SHOT) Steering Group (2012) The 2011 Annual SHOT Report. SHOT.

Bolton-Maggs, P., Poles, D., Watt, A., Thomas, D., Cohen, H. \& on behalf of the Serious Hazards of Transfusion (SHOT) Steering Group (2013) The 2012 Annual SHOT Report. (ed. by Bolton-Maggs, P.), p. 200. Serious Hazards of Transfusion (SHOT).

Burnett, A.K., Hills, R.K., Milligan, D., Kjeldsen, L., Kell, J., Russell, N.H., Yin, J.A.L., Hunter, A., Goldstone, A.H. \& Wheatley, K. (2011) Identification of Patients With Acute Myeloblastic Leukemia Who Benefit From the Addition of Gemtuzumab Ozogamicin: Results of the MRC AML15 Trial. Journal of Clinical Oncology, 29, 369-377. 
Butler, C., Doree, C., Estcourt, L.J., Trivella, M., Hopewell, S., Brunskill, S.J., Stanworth, S. \& Murphy, M.F. (2013) Pathogen-reduced platelets for the prevention of bleeding. Cochrane database of systematic reviews (Online), 3, CD009072.

Cameron, B., Rock, G., Olberg, B. \& Neurath, D. (2007) Evaluation of platelet transfusion triggers in a tertiary-care hospital. Transfusion, 47, 206-211.

Cancer Research UK (2013), http://www.cancerresearchuk.org/cancer-info/cancerstats/incidence/ [Accessed $13^{\text {th }}$ February 2013].

CDC (2012) United States Cancer Statistics (USCS). National Program of Cancer Registries (NPCR). http://apps.nccd.cdc.gov/uscs/ [Accessed $7^{\text {th }}$ February 2013].

Charlton, A., Wallis, J., Robertson, J., Watson, D., Iqbal, A., \& Tinegate, H. (2014). Where did platelets go in 2012? A survey of platelet transfusion practice in the north of England. Transfusion Medicine [In Press]

Chihara, D., Ito, H., Matsuda, T., Shibata, A., Katsumi, A., Nakamura, S., Tomotaka, S., Morton, L.M., Weisenburger, D.D. \& Matsuo, K. (2014) Differences in incidence and trends of haematological malignancies in Japan and the United States. British Journal of Haematology, 164, 536-545.

Coleman, M., Rachet, B., Woods, L., Mitry, E., Riga, M., Cooper, N., Quinn, M., Brenner, H. \& Esteve, J. (2004) Trends and socioeconomic inequalities in cancer survival in England and Wales up to 2001. British Journal of Cancer, 90, 1367-1373.

Commonwealth of Australia (2008) National Blood Authority annual report 2007-2008.

Commonwealth of Australia (2013) National Blood Authority annual report 2012-13.

De la Serna, J., Montesinos, P., Vellenga, E., Rayon, C., Parody, R., Leon, A., Esteve, J., Bergua, J.M., Milone, G., Deben, G., Rivas, C., Gonzalez, M., Tormo, M., az-Mediavilla, J., Gonzalez, J.D., Negri, S., Amutio, E., Brunet, S., Lowenberg, B. \& Sanz, M.A. (2008) Causes and prognostic factors of 
remission induction failure in patients with acute promyelocytic leukemia treated with all-trans retinoic acid and idarubicin. Blood, 111, 3395-3402.

Estcourt, L.J., Birchall, J., Lowe, D., Grant-Casey, J., Rowley, M. \& Murphy, M.F. (2012) Platelet transfusions in haematology patients: are we using them appropriately? Vox Sanguinis, 103, 284-293.

Estcourt, L.J., Stanworth, S.J., Collett, D. \& Murphy, M.F. (2014) Intracranial haemorrhage in thrombocytopenic haematology patients-a nested case-control study: the InCiTe study protocol. BMJ Open, 4, e004199.

Fernandez de Larrea, C., Jimenez, R., Rosinol, L., Gine, E., Tovar, N., Cibeira, M. T., Fernandez-Aviles, F., Martinez, C., Rovira, M., \& Blade, J. (2014) Pattern of relapse and progression after autologous SCT as upfront treatment for multiple myeloma. Bone Marrow Transplantation 49, 223-227.

Fielding, A.K., Richards, S.M., Chopra, R., Lazarus, H.M., Litzow, M.R., Buck, G., Durrant, I.J., Luger, S.M., Marks, D.I., Franklin, I.M., McMillan, A.K., Tallman, M.S., Rowe, J.M. \& Goldstone, A.H. (2007) Outcome of 609 adults after relapse of acute lymphoblastic leukemia (ALL); an MRC UKALL12/ECOG 2993 study. Blood, 109, 944-950.

Garland, A., Olafson, K., Ramsey, C.D., Yogendran, M. \& Fransoo, R. (2013) Epidemiology of critically ill patients in intensive care units: a population-based observational study. Critical Care Medicine, 17, R212.

Gratwohl, A., Baldomero, H., Frauendorfer, K., Rocha, V., Apperley, J., Niederwieser, D., Joint Accreditation Committee of the International Society for Cellular, T., European Group for, B. \& Marrow Transplantation, E. (2008) The EBMT activity survey 2006 on hematopoietic stem cell transplantation: focus on the use of cord blood products. Bone Marrow Transplantation, 41, 687-705. 
Gratwohl, A., Baldomero, H., Frauendorfer, K., Urbano-Ispizua, A., Joint Accreditation Committee, I.S.f.C.T., European Group for, B. \& Marrow, T. (2006) EBMT activity survey 2004 and changes in disease indication over the past 15 years. Bone Marrow Transplantation, 37, 1069-1085.

Gratwohl, A., Baldomero, H., Passweg, J., Urbano-Ispizua, A., European Group for, B. \& Marrow Transplantation . Accreditation, C. (2002) Increasing use of reduced intensity conditioning transplants: report of the 2001 EBMT activity survey. Bone Marrow Transplantation, 30, 813831.

Gratwohl, A., Baldomero, H., Schmid, O., Horisberger, B., Bargetzi, M. \& Urbano-Ispizua, A. (2005) Change in stem cell source for hematopoietic stem cell transplantation (HSCT) in Europe: a report of the EBMT activity survey 2003. Bone Marrow Transplantation, 36, 575-590.

Gratwohl, A., Baldomero, H., Schwendener, A., Gratwohl, M., Apperley, J., Frauendorfer, K. \& Niederwieser, D. (2011) The EBMT activity survey 2008: impact of team size, team density and new trends. Bone Marrow Transplantation, 46, 174-191.

Gratwohl, A., Baldomero, H., Schwendener, A., Rocha, V., Apperley, J., Frauendorfer, K., Niederwieser, D., Joint Accreditation Committee of the International Society for Cellular, T., European Group for, B. \& Marrow, T. (2009) The EBMT activity survey 2007 with focus on allogeneic HSCT for AML and novel cellular therapies. Bone Marrow Transplantation, 43, 275-291.

Gratwohl, A., Schmid, O., Baldomero, H., Horisberger, B., Urbano-Ispizua, A., Accreditation Committee of the European Group for, B. \& Marrow, T. (2004) Haematopoietic stem cell transplantation (HSCT) in Europe 2002. Changes in indication and impact of team density. A report of the EBMT activity survey. Bone Marrow Transplantation, 34, 855-875.

Greeno, E., McCullough, J. \& Weisdorf, D. (2007) Platelet utilization and the transfusion trigger: a prospective analysis. Transfusion, 47, 201-205. 
Heddle, N., Cook, R., Tinmouth, A., Kouroukis, C., Hervig, T., Klapper, E., JM, B., Szczepiorkowski, Z., AuBuchon, J., Barty, R. \& Lee, K. (2009) A randomized controlled trial comparing standard and low dose strategies for transfusion of platelets (SToP) to patients with thrombocytopenia. Blood, 113, 1564-1573.

Heddle, N.M., Arnold, D.M., Boye, D., Webert, K.E., Resz, I. \& Dumont, L.J. (2008) Comparing the efficacy and safety of apheresis and whole blood-derived platelet transfusions: a systematic review. Transfusion, 48, 1447-1458.

Henry, D.A., Carless, P.A., Moxey, A.J., O'Connell, D., Stokes, B.J., Fergusson, D.A. \& Ker, K. (2011) Antifibrinolytic use for minimising perioperative allogeneic blood transfusion. Cochrane Database of Systematic Reviews, CD001886.

Jones, A., Birchall, J., Roberts, P., Davies, L., Webb, M., Cooke, S.J., Mead, K., MacRate, E., Thompson, P. \& McMahon, J. (2013) A survey of where and why platelets are used in hospitals in the South West region of England. Transfusion Medicine, 23, PO34.

Ma, X. (2012) Epidemiology of myelodysplastic syndromes. Am J Med, 125, S2-5.

Ma, X., Does, M., Raza, A. \& Mayne, S.T. (2007) Myelodysplastic syndromes: incidence and survival in the United States. Cancer, 109, 1536-1542.

MacLennan, S., Harding, K., Llewelyn, L., Choo, L., Bakrania, L., Massey, E. \& Williamson, L. (2013) Comparison of platelets stored for 2-5 vs 6-7 days in preventing and treating haemorrhage in thrombocytopeinc patients - a randomised controlled trial. Vox Sanguinis, 105, 42.

Miller, Y., Bachowski, G., Benjamin, R., Eklund, D.K., Hibbards, A.J., Lightfoor, T., Meena-Leist, C., Quaraishy, N., Sapatnekar, S., Squires, J., Strupp, A., Vassallo, R. \& Weiss, J. (2007) Practice Guidelines for Blood Transfusion. In: A Compilation from Recent Peer-Reviewed Literature (ed. by American National Red Cross). American National Red Cross. 
Milligan, D.W., Wheatley, K., Littlewood, T., Craig, J.I.O., Burnett, A.K. \& for the NCRI Haematological Oncology Clinical Studies Group (2006) Fludarabine and cytosine are less effective than standard ADE chemotherapy in high-risk acute myeloid leukemia, and addition of G-CSF and ATRA are not beneficial: results of the MRC AML-HR randomized trial. Blood, 107, 4614-4622.

National Cancer Institute (2013a) Surveillance, Epidemiology, and End Results Program (SEER) Stat Fact Sheets: Hodgkin Lymphoma. http://seer.cancer.gov/statfacts/ [Downloaded February $24^{\text {th }} 2014$ ] National Cancer Institute (2013b) Surveillance, Epidemiology, and End Results Program (SEER) Stat Fact Sheets: Leukemia. http://seer.cancer.gov/statfacts/ [Downloaded February $24^{\text {th }} 2014$ ] National Cancer Institute (2013c) Surveillance, Epidemiology, and End Results Program (SEER) Stat Fact Sheets: Myeloma. http://seer.cancer.gov/statfacts/ [Downloaded February $24^{\text {th }} 2014$ ] National Cancer Institute (2013d) Surveillance, Epidemiology, and End Results Program (SEER) Stat Fact Sheets: Non-Hodgkin Lymphoma. http://seer.cancer.gov/statfacts/ [Downloaded February $24^{\text {th }}$ 2014]

Neukirchen, J., Schoonen, W.M., Strupp, C., Gattermann, N., Aul, C., Haas, R. \& Germing, U. (2011) Incidence and prevalence of myelodysplastic syndromes: data from the Dusseldorf MDSregistry. Leukemia Research, 35, 1591-1596.

Office of National Statistics (ONS) (2013a) Mid-year population estimates for the United Kingdom by country, annual mid-2001 to mid-2012. (ed. by figure1_tcm77-346352) Office of National Statistics. www.ons.gov.uk [Downloaded February 24 ${ }^{\text {th }} 2014$ ]

Office of National Statistics (ONS) (2013b) Mid-1971 to Mid-2012 population estimates: quinary age groups for consituent countries in the United Kingdom; estimated resident population. (MYE6TS3C) Office of National Statistics. www.ons.gov.uk [Downloaded April 25 ${ }^{\text {th }}$ 2014]

Office of National Statistics (ONS) (2013c) 2012-based national population projections. Office of National Statistics. www.ons.gov.uk [Downloaded February 26 ${ }^{\text {th }} 2014$ ] 
Office of National Statistics (ONS) (2012) Cancer incidence and mortality tables and charts tcm77259491. Office of National Statistics. www.ons.gov.uk [Downloaded February $5^{\text {th }} 2013$ ]

Passweg, J.R., Baldomero, H., Bregni, M., Cesaro, S., Dreger, P., Duarte, R.F., Falkenburg, J.H., Kroger, N., Farge-Bancel, D., Gaspar, H.B., Marsh, J., Mohty, M., Peters, C., Sureda, A., Velardi, A., Ruiz de Elvira, C., Madrigal, A., European Group for, B. \& Marrow, T. (2013) Hematopoietic SCT in Europe: data and trends in 2011. Bone Marrow Transplantation, 48, 1161-1167.

Passweg, J.R., Baldomero, H., Gratwohl, A., Bregni, M., Cesaro, S., Dreger, P., de Witte, T., Farge-Bancel, D., Gaspar, B., Marsh, J., Mohty, M., Peters, C., Tichelli, A., Velardi, A., de Elvira, C.R., Falkenburg, F., Sureda, A., Madrigal, A., European Group for, B. \& Marrow, T. (2012) The EBMT activity survey: 1990-2010. Bone Marrow Transplantation, 47, 906-923.

Patel, B., Kirkland, K., Szydlo, R., Pearce, R., Clark, R., Craddock, C., Liakopoulou, E., Fielding, A., Mackinnon, S., Olavarria, E., Potter, M., Russell, N., Shaw, B., Cook, G., Goldstone, A. \& Marks, D. (2009) Favorable outcomes with alemtuzumab-conditioned unrelated donor stem cell transplantation in adults with high-risk Philadelphia chromosome-negative acute lymphoblastic leukemia in first complete remission. Haematologica, 94, 1399-1406.

Pendry, K. \& Davies, T. (2011) An audit of the use and wastage in the North West of England and North Wales - where have all the platelets gone? Blood and Transfusion Matters, 34, 17-19.

Pietersz, R.N.I., Reesink, H.W., Panzer, S., Gilbertson, M.P., Borosak, M.E., Wood, E.M., Leitner, G.C., Rabitsch, W., Ay, C., Lambermont, M., Deneys, V., Sondag, D., Compernolle, V., Legrand, D., Francois, A., Tardivel, R., Garban, F., Sawant, R.B., Rebulla, P., Handa, M., Ohto, H., Kerkhoffs, J.L.H., Brand, A., Zhiburt, E., Cid, J., Escolar, G., Lozano, M., Puig, L., Knutson, F., Hallbook, H., Lubenow, N., Estcourt, L., Stanworth, S., Murphy, M.F., Williams, L., Mraz, D.L., Ross, R.L. \& Snyder, E. (2012) Prophylactic platelet transfusions. Vox Sanguinis, 103, 159-176. 
Qureshi, H., Lowe, D., Dobson, P., Grant-Casey, J., Parris, E., Dalton, D., Hickling, K., Waller, F., Howell, C. \& Murphy, M. (2007) National comparative audit of the use of platelet transfusions in the UK. Transfusion Clinique et Biologique, 14, 509-513.

Rachet, B., Maringe, C., Nur, U., Quaresma, M., Shah, A., Woods, L.M., Ellis, L., Walters, S., Forman, D., Steward, J. \& Coleman, M.P. (2009) Population-based cancer survival trends in England and Wales up to 2007: an assessment of the NHS cancer plan for England. The Lancet Oncology, 10, 351-369.

Report of the US Department of Health and Human Services (2011) The 2009 national blood collection and utilization survey report. (ed. by US Department of Health and Human Services). Office of the Assistant Secretary for Health, Washington, DC.

Rysler, C., Stoffel, N., Buser, A., Gratwohl, A., Tsakiris, D.A. \& Stern, M. (2010) Effect of beta-blockers, Ca2+antagonists, and benzodiazepines on bleeding incidence in patients with chemotherapy induced thrombocytopenia. Platelets, 21, 77-83.

Scottish Intensive Care Society Audit Group (2013) Audit of critical care in Scotland 2013 reporting on 2012.

Slichter, S.J., Kaufman, R.M., Assmann, S.F., McCullough, J., Triulzi, D.J., Strauss, R.G., Gernsheimer, T.B., Ness, P.M., Brecher, M.E., Josephson, C.D., Konkle, B.A., Woodson, R.D., Ortel, T.L., Hillyer, C.D., Skerrett, D.L., McCrae, K.R., Sloan, S.R., Uhl, L., George, J.N., Aquino, V.M., Manno, C.S., McFarland, J.G., Hess, J.R., Leissinger, C. \& Granger, S. (2010) Dose of prophylactic platelet transfusions and prevention of hemorrhage. New England Journal of Medicine, 362, 600-613.

Snyder-Ramos, S.A., Mohnle, P., Weng, Y.S., Bottiger, B.W., Kulier, A., Levin, J. \& Mangano, D.T. (2008) The ongoing variability in blood transfusion practices in cardiac surgery. Transfusion, 48, 12841299. 
Spiess, B.D., Royston, D., Levy, J.H., Fitch, J., Dietrich, W., Body, S., Murkin, J. \& Nadel, A. (2004) Platelet transfusions during coronary artery bypass graft surgery are associated with serious adverse outcomes. Transfusion, 44, 1143-1148.

Stanworth, S.J., Estcourt, L.J., Llewelyn, C.A., Murphy, M.F., Wood, E.M.; for the TOPPS study investigators (2014). Impact of prophylactic platelet transfusions on bleeding events in patients with hematologic malignancies: a sub-group analysis of a randomized trial. Transfusion [Early online publication April 14 ${ }^{\text {th }}$ 2014]

Stanworth, S.J., Estcourt, L.J., Powter, G., Kahan, B., Dyer, C., Choo, L., Bakrania, L., Llewelyn, C., Littlewood, T., Soutar, R., Norfolk, D., Copplestone, A., Smith, N., Kerr, P., Jones, G., Raj, K., Westerman, D., Szer, J., Jackson, N., Bardy, P., Plews, D., Lyons, S., Bielby, L., Wood, E.M. \& Murphy, M. (2013a) A no-prophylaxis platelet transfusion strategy for hematologic cancers. New England Journal of Medicine, 368, 1771-1780.

Stanworth, S.J., Walsh, T.S., Prescott, R.J., Lee, R.J., Watson, D.M. \& Wyncoll, D.L. (2013b) Thrombocytopenia and platelet transfusion in UK critical care: a multicenter observational study. Transfusion, 53, 1050-1058.

Taylor, C., Cohen, H., Jones, H., Asher, D., Brant, L., Chapman, C., Davies, T., Gray, A., Milkins, C., Norfolk, D., Tinegate, H. \& on behalf of the SHOT Steering Group (2008) Annual Report 2007 Serious Hazards of Transfusion (SHOT).

Taylor, C.E., Cohen, H., Mold, D., Jones, H., et al \& on behalf of the Serious Hazards of Transfusion (SHOT) Steering Group (2009) The 2008 Annual SHOT Report.

The Health and Social Care Information Centre (2013) Adult critical care in England April 2011 to March 2012. www.ic.nhs.uk [Downloaded $27^{\text {th }}$ February 2014]. 
Tinegate, H., Chattree, S., Iqbal, A., Plews, D., Whitehead, J., Wallis, J.P. \& Northern Regional Transfusion, C. (2013) Ten-year pattern of red blood cell use in the North of England. Transfusion, 53, 483-489.

van der Poel, C., Janssen, M. \& Behr-Gross, M.-E. (2011a) Trends and observations on the collection, testing and use of blood and blood components in Europe. 2001-2005 report. (ed. by Directorate for the Quality of Medicines and HealthCare of the Council of Europe (EDQM)). van der Poel, C., Janssen, M. \& Behr-Gross, M.-E. (2011b) The collection, testing and use of blood components in Europe. 2006 Report. (ed. by Directorate for the Quality of Medicines and HealthCare of the Council of Europe (EDQM)).

van der Poel, C., Janssen, M. \& Behr-Gross, M.-E. (2011c) The collection, testing and use of blood components in Europe. 2007 report. (ed. by Directorate for the Quality of Medicines and Healthcare of the Council of Europe (EDQM)).

van der Poel, C., Janssen, M. \& Behr-Gross, M.-E. (2011d) The collection, testing and use of blood and blood components in Europe. 2008 report. (ed. by Directorate for the Quality of Medicines and Healthcare of the Council of Europe (EDQM)).

Wandt, H., Schaefer-Eckart, K., Wendelin, K., Pilz, B., Wilhelm, M., Thalheimer, M., Mahlknecht, U., Ho, A., Schaich, M., Kramer, M., Kaufmann, M., Leimer, L., Schwerdtfeger, R., Conradi, R., Dolken, G., Klenner, A., Hanel, M., Herbst, R., Junghanss, C. \& Ehninger, G. (2012) Therapeutic platelet transfusion versus routine prophylactic transfusion in patients with haematological malignancies: an open-label, multicentre, randomised study. Lancet, 380, 1309-1316.

Wardrop, D., Estcourt, L., Brunskill, S.J., Doree, C., Trivella, M., Stanworth, S. \& Murphy, M. (2013) Antifibrinolytics (lysine analogues) for the prevention of bleeding in patients with haematological disorders. Cochrane database of systematic reviews (Online), CD009733. 
Wells, A.W., Llewelyn, C.A., Casbard, A., Johnson, A.J., Amin, M., Ballard, S., Buck, J., Malfroy, M., Murphy, M.F., \& Williamson, L.M. (2009). The EASTR study: a new approach to determine the reasons for transfusion in epidemiological studies. Transfusion Medicine;19:315-328.

Whitaker, B.I., Green, W.-J., King, M.R., Leibeg, L.L., Mathew, S.M., Schlumpf, K.S. \& Schreiber, G.B. (2008) The 2007 national blood collection and utilization report. (ed. by US Department of Health \& Human Services). DHHS, Washington DC.

Whitaker, B.I. \& Hinkins, S. (2013) The 2011 national blood collection and utilization survey report. (ed. by US Department of Health and Human Services). US Department of Health and Human Services, Rockville, Maryland.

Whitaker, B.I. \& Sullivan, M. (2007) The 2005 nationwide blood collection and utilization survey. (ed. by US Department of Health \& Human Services), Washington DC. 
Table 1 Change in platelet use per 1000 population from period 2001-2002 to 2007-2008* for seven European countries.

\begin{tabular}{|l|c|c|c|c|}
\hline Country & $\begin{array}{c}\text { Total number of } \\
\text { platelet } \\
\text { components used } \\
2008\end{array}$ & \multicolumn{2}{|c|}{$\begin{array}{c}\text { Mean number of platelet } \\
\text { per 1000 population }\end{array}$} & $\begin{array}{c}\text { Change in } \\
\text { demand }\end{array}$ \\
\cline { 3 - 5 } & 36,300 & $2001-2002$ & $2007-2008$ & \\
\hline Austria & 65,030 & 4.61 & 3.98 & $+27 \%$ \\
\hline Belgium & 30,349 & 2.20 & 6.14 & $+33 \%$ \\
\hline Czech & & & 2.58 & $+17 \%$ \\
\hline Republic & 472,346 & 3.27 & 5.76 & $+72 \%$ \\
\hline Germany & 50,784 & 6.42 & 3.08 & $-51 \%$ \\
\hline Netherlands & 38,941 & 3.67 & 4.18 & $+14 \%$ \\
\hline Sweden & 27,669 & 2.23 & 3.31 & $+49 \%$ \\
\hline Switzerland & & & & \\
\hline
\end{tabular}

*Data derived from the European Committee on Blood Transfusion Reports.(van der Poel, et al 2011a, van der Poel, et al 2011b, van der Poel, et al 2011c, van der Poel, et al 2011d) Data for all countries (excluding UK) within the reports that issued at least 300,000 units of red blood cell components per year in 2008 and had complete data for both time periods. 
Table 2

Additional data that would enable more accurate modelling of current and future platelet component demand at a national level

- Age of platelet component recipients

- Underlying diagnosis/ patient group of platelet component recipients

- Type of platelet component issued 
Figure 1: Platelet (A) and red blood cell (RBC) component (B) demand for the UK for the period 2001 to 2012, adjusted to the UK population (per 1000 population). Data from SHOT Annual Reports and Office of National Statistics (Bolton-Maggs, et al 2012, Office of National Statistics (ONS) 2013a, Taylor, et al 2008, Taylor, et al 2009).

Figure 2: Percentage Change in European Age-Standardised Three Year Average Incidence Rates, in (A) Males and (B) Females, UK, 1999-2001 and 2008-2010 for the major types of haematological malignancies and all cancers *excluding non-melanoma skin cancer (Cancer Research UK 2013).

Figure 3: (A) Ten year relative survival (\%), adults (15-99 years), for patients diagnosed with haematological malignancies and all cancers, England and Wales: survival trends for 1971-2007. Data for patients diagnosed between 1971-1991 actual survival data, and data for patients diagnosed in 2007 hybrid survival data (predicted) (Coleman, et al 2004, Rachet, et al 2009). (B) Five year relative survival (\%), for patient diagnosed with haematological malignancies, United States: survival trends for 1975 to 2010. Data from SEER9 Incidence \& US Mortality 1975-2010, all races, both sexes, all rates are age adjusted (National Cancer Institute 2013a, National Cancer Institute 2013b, National Cancer Institute 2013c, National Cancer Institute 2013d).

Figure 4: Number of Haemopoietic stem cell transplants (HSCT) performed in Europe from 2001 to 2011 according to the annual European Bone Marrow Transplantation (EBMT) Activity Surveys (Baldomero, et al 2011, Gratwohl, et al 2008, Gratwohl, et al 2006, Gratwohl, et al 2002, Gratwohl, et al 2005, Gratwohl, et al 2011, Gratwohl, et al 2009, Gratwohl, et al 2004, Passweg, et al 2013, Passweg, et al 2012). 